\title{
The Chemical Estimation of Vitamin $\mathbf{E}$ in Vegetable Oils
}

\author{
By J. TOŠIĆ́ AND T. MOORE, Dunn Nutritional Laboratory, University of Cambridge, \\ and Medical Research Council
}

(Received 28 June 1945)

The chemical methods for estimation of vitamin $\mathbf{E}$, recommended in the literature, are all based on the oxidation of a hydroquinone nucleus which is present in all modifications of tocopherol. This nucleus can either be oxidized in such a way as to give a coloured ' product, or its reducing power may be measured and hence the quantity of tocopherol calculated. The latter principle is employed in the gold chloride potentiometric method of Karrer \& Keller (1938, 1939) and in the colorimetric methods based on the $\mathrm{FeCl}_{3}-\alpha: \alpha^{\prime}$-dipyridyl reaction of Emmerie \& Engel (1938).

The method of Furter \& Meyer (1939) is not specific; the red colour which develops on treatment of tocopherol with concentrated $\mathrm{HNO}_{3}$ is given also by its biologically inactive oxidation product (Lester Smith \& Bailey, 1939). A method of assaying $\alpha$-tocopherol acetate by hydrolyzing with sulphuric acid and titrating with ceric sulphate, recommended by the British Pharmaceutical Codex (1942), opens new possibilities, but apparently has not yet been applied to the estimations of tocopherol in its natural sources. The gold chloride potentiometric method requires elaborate apparatus, and is more complicated than the $\alpha: \alpha^{\prime}$-dipyridyl method, which is simple, rapid and accurate if interfering substances are removed from the unsaponifiable matter before reagents are applied.

In this paper we describe means for preparing suitable extracts to which the $\alpha: \alpha^{\prime}$-dipyridyl reaction can be successfully applied so as to secure results consistent with biological values for natural oils as obtained by other workers (Olcott, 1934; Drummond, Singer \& MacWalter, 1935) and with such tests as we have so far performed. Preliminary accounts of the work have already been given (Moore \& Tošić, 1943; Tošić \& Moore, 1944).

\section{EXPERIMENTAL}

\section{Experimental basis of chemical method for estimation of vitamin $E$}

The ability to produce a red colour with ferric chloride and $\alpha: \alpha^{\prime}$-dipyridyl is not a specific property of tocopherols, but is shown by many reducing agents. Emmerie \& Engel (1938) found that both carotene and vitamin A produced colour, so that it was necessary either to remove them before the estimation of vitamin $\mathbf{E}$, or to make an appropriate correction. It is now clear that several other complications must be faced before it can be safely assumed that only vitamin $\mathrm{E}$ is being estimated. If the reaction is applied directly to oils without saponification our first consideration must be that esterified tocopherols do not produce colour. Since tocopherol is believed to be present in the frre state in all its natural sources this criticism may not be serious except when we are dealing with oils artificially fortified with synthetic esters. Another objection is that oils may contain pigments which interfere with the assessment of the correction for carotenoids. These pigments, together with sterols, have been removed by Parker \& McFarlane (1940) by means of extraction with $85 \% \mathrm{H}_{2} \mathrm{SO}_{4}$. We are, however, still faced with the finding of Kaunitz (1944) that the presence of oil seriously interferes with the development of colour by tocopherol. The objection to saponification, by ordinary methods, is that substantial losses of tocopherol may occur. Even in examining the unsaponifiable fraction, moreover, precautions have still to be taken. It may be necessary not only to correct for the presence of carotenoids, but in our experience to remove other reducing substances which may affect the accuracy of the method much more seriously.

For a successful application of the $\alpha: \alpha^{\prime}$-dipyridyl reaction therefore it is necessary: $(a)$ to saponify the oil under conditions which prevent the destruction of vitamin $\mathrm{E},(b)$ to separate interfering substances from the unsaponifiable matter, (c) to make a correction for the reducing power of any carotenoids which cannot conveniently be removed, and $(d)$ to protect the solution against sunlight during the estimation (Lester Smith \& Bailey, 1939).

\section{Choice of light filters}

With the use of Zeiss Pulfrich Photometer, maximum transmission of the red ferrous- $\alpha: \alpha^{\prime}$-dipyridyl complex formed by reaction with $\alpha$-tocopherol was found to be at about $520 \mathrm{~m} \mu$. The most suitable filters for the colorimetric estimation should therefore be the green S 50 or S53 filters. With an S53 filter, a calibration curve for the reducing power of synthetic $\alpha$-tocopherol proved to be a straight line for $0-168 \mu \mathrm{g}$. of $\alpha$-tocopherol in the reagent mixture. The amount of tocopherol, as $\mu \mathrm{g} . / \mathrm{ml}$. of solution, could be calculated by multiplying the extinction 
coefficient as read on the instrument by a factor of $166 \cdot 6$.

In calculating the quantities of $\alpha$-tocopherol, and other substances in unsaponifiable matter which reduce $\mathrm{FeCl}_{3}$ in $\alpha: \alpha^{\prime}$-dipyridyl reaction, this factor was always used. All the data regarding $\mathrm{FeCl}_{3}-\mathrm{re}$ ducing substances have been expressed in terms of 'apparent' synthetic $\alpha$-tocopherol.

\section{Stability of $\alpha$-tocopherol during saponification in absence and presence of pyrogallol}

Since Lester Smith \& Bailey (1939) were unable to prevent the loss of tocopherol on saponification by working as far as possible in an atmosphere of inert gas, some other form of protection was necessary. A novel procedure involving the addition of pyrogallol was tried. It was expected that, during treatment of the oils with hot ethanolic potash, this substance would compete with tocopherol for the available oxygen, and so reduce the loss of vitamin. A series of recovery tests on synthetic $\alpha$-tocopherol and its acetate after a saponification procedure was carried out in absence and presence of pyrogallol.

(a) Recovery of $\alpha$-tocopherol. To $1 \mathrm{ml}$. of an ethanol solution of synthetic $\alpha$-tocopherol, containing a quantity likely to be found in oil samples to be examined, $1 \mathrm{ml}$. freshly prepared $10 \%$ pyrogallol solution in ethanol was added. For each sample containing pyrogallol a control without pyrogallol (but with $1 \mathrm{ml}$. ethanol added) was prepared. The contents wire heated on a water-bath, conc. KOH solution sufficient to saponify $1 \mathrm{~g}$. of oil was added, and heating continued for a short time until saponification was complete. Distilled water was then added, and the vitamin extracted with diethyl ether. Excess of pyrogallol was readily removed by washing with water. The extracts were then evaporated under reduced pressure in a hot waterbath and the 'unsaponifiable' matter, in this case $\alpha$-tocopherol only, was examined colorimetrically with $\mathrm{FeCl}_{3}-\alpha: \alpha^{\prime}$ dipyridyl reagent. The results of these tests indicate (Table $1 a$ ) that pyrogallol eliminates the serious losses which occur during saponification.

(b) Recovery of $\alpha$-tocopherol from its acetate. When $\alpha$-tocopherol acetate is saponified as described under $(a)$, the $\alpha$-tocopherol formed can be estimated colorimetrically in the 'unsaponifiable' matter. Losses due to saponification in the absence of pyrogallol are considerable. On the other hand, the pyrogallol procedure secures a satisfactory recovery (Table $1 b$ ).

The tests described under (a) and (b) show that the losses of $\alpha$-tocopherol occurring during the alkaline treatment amounted on the average to about half of the vitamin added, while in the presence of pyrogallol recovery was almost complete.

\section{Pyrogallol procedure applied to oils}

The pyrogallol procedure was applied to natural oils to assess further the accuracy of the method.
Table 1. Recovery of synthetic $\alpha$-tocopherol in presence and absence of pyrogallol

\begin{tabular}{|c|c|c|}
\hline & Without pyrogallol & With pyrogallol \\
\hline $\begin{array}{l}\text { pherol } \\
\text { mg. added) }\end{array}$ & $\begin{array}{c}\% \\
\text { recovery }\end{array}$ & $\begin{array}{c}\% \\
\text { recovery }\end{array}$ \\
\hline
\end{tabular}

(a) Recovery of $\alpha$-tocopherol in absence of oil

$\begin{array}{lllll}1.08 & 0.63 & 58.7 & 1.07 & 99 \cdot 2 \\ 1.08 & 0.62 & 57.2 & 1.06 & 98.2 \\ 1.08 & 0.36^{*} & 33.3^{*} & 1.06 & 98.2\end{array}$

(b) Recovery of $\alpha$-tocopherol from its acetate in absence of oil

$\begin{array}{lllll}\mathbf{1} .78 & 0.66 & \mathbf{3 7 . 7} & \mathbf{1} \cdot 76 & \mathbf{9 8 . 8} \\ \mathbf{1 . 7 8} & \mathbf{1 . 0 4} & \mathbf{5 8 . 4} & \mathbf{1 . 7 7} & \mathbf{9 9 . 4} \\ \mathbf{1 . 0 8} & \mathbf{0 . 5 7} & \mathbf{5 2 . 8} & \mathbf{1 . 0 7} & \mathbf{9 9 . 2} \\ \mathbf{l} .08 & \mathbf{0 . 9 2} & \mathbf{8 5 . 2} & \mathbf{1 . 0 6} & \mathbf{9 8 . 2}\end{array}$

(c) Recovery of $\alpha$-tocopherol from its acetate in presence of oil

$\begin{array}{lllll}2.06 \dagger & 1.84 & 89 \cdot 3 & 2 \cdot 02 & 98 \cdot 2 \\ 2.06 \dagger & 1 \cdot 80 & 87 \cdot 4 & 2 \cdot 03 & 98 \cdot 6 \\ 2.06 \dagger & 1 \cdot 72 & 83 \cdot 2 & 2 \cdot 01 & \mathbf{9 7 \cdot 5} \\ 2.06 \dagger & 1.77 & 86 \cdot 0 & 2.03 & 98 \cdot 6\end{array}$

* In this case $1 \mathrm{ml}$. of distilled water was added to the ethanol solution of the vitamin.

t These figures represent total $\mathrm{FeCl}_{3}$-reducing substances of the oil which are made up as follows: $1.82 \mathrm{mg}$. $\alpha$-tocopherol, added in the form of its acetate, $+0.24 \mathrm{mg}$. found in the arachis oil itself by our pyrogallol method.

When $\alpha$-tocopherol acetate was dissolved in arachis oil, and the colorimetric estimation done on the unsaponifiable matter, the results (Table $1 c$ ) indicate that during saponification pyrogallol quantitatively protects both tocopherol and the other substances which reduce $\mathrm{FeCl}_{3}$. During the saponification in the absence of pyrogallol the losses amounted to 10.7-16.8\% (average 13.5\%). These losses were much smaller than those sustained when $\alpha$-tocopherol or its acetate without oil were saponified in the absence of pyrogallol (Tables $1 a$ and $1 b$ ). Probably the oil contains substances which partially protect the vitamin during the saponification.

Table 2. Agreement of triplicates by the pyrogallol method

$\mathrm{FeCl}_{3}$-redùcing substances* Maxi$\mu \mathrm{g} . / \mathrm{g}$. of oil) $\quad$ spread

Oil $\overbrace{1} \quad 2 \quad 3 \quad$ Mean as \% of

$\begin{array}{llllll}\text { Wheat-germ } & 3180 & 3080 & 3100 & 3120 & \mathbf{3} \cdot 20\end{array}$

(freshly extracted)

$\begin{array}{llllll}\text { Wheat-germ } & 558 & 549 & 541 & 549 & 3.10\end{array}$

(old sample)t

Tung

558

$\begin{array}{lllll}2391 & 2361 & 2359 & 2370 & 1.36\end{array}$

$\begin{array}{lrrrrr}\text { Soya-bean } & 1355 & 1357 & 1361 & 1356 & 0.44\end{array}$

$\begin{array}{lrrrrr}\text { Cotton-seed (crude) } & 936 & 969 & 937 & 947 & 3.48\end{array}$

$\begin{array}{llllll}\text { Cotton-seed } & 576 & 594 & 591 & 588 & 2.56\end{array}$

* Correction for carotenoid pigments has been deducted from the data in this table.

+ A sample of wheat-germ oil, extracted over 10 years ago and kept in a store at room temperature. 
The reproducibility of results in saponification with pyrogallol was tested on several vegetable oils (Table 2). A maximum difference between $\mathrm{FeCl}_{3}$-reducing substances in triplicate estimations amounted to a maximum of $3.48 \%$, which is within the experimental error of estimation.

For comparing saponification procedures, with and without pyrogallol, we have examined a number of freshly extracted oils (Table 3). An average loss

\section{Table 3. $\mathrm{FeCl}_{3}$-reducing substances of freshly extracted oils}

\begin{tabular}{|c|c|c|c|}
\hline \multirow[b]{2}{*}{ Oil* } & \multicolumn{2}{|c|}{$\begin{array}{c}\mathrm{FeCl}_{\mathrm{s}} \text {-reducing } \\
\text { substances } \dagger \\
(\mu \mathrm{g} . / \mathrm{g} \text {. of oil) }\end{array}$} & \multirow{2}{*}{$\begin{array}{c}\% \\
\text { difference } \\
\text { between } \\
\text { the two } \\
\text { methods }\end{array}$} \\
\hline & $\begin{array}{c}\text { With } \\
\text { pyrogallol }\end{array}$ & 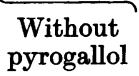 & \\
\hline Wheat-germ & 3120 & 2470 & $20 \cdot 8$ \\
\hline Soya-bean & 1356 & 1070 & $21 \cdot 0$ \\
\hline Firsts castor & 909 & 814 & 10.4 \\
\hline Crude linseed & 729 & 624 & $14 \cdot 4$ \\
\hline Cotton-seed & 696 & 535 & $23 \cdot 0$ \\
\hline Crude rape & 661 & 512 & 22.5 \\
\hline Crude sesame & 527 & 430 & $18 \cdot 3$ \\
\hline Ground-nut & 268 & 249 & 7.0 \\
\hline Crude cocoa-butter & 220 & 148 & $32 \cdot 7$ \\
\hline Coconut & nil & nil & nil \\
\hline Palm-kernel & nil & nil & nil \\
\hline
\end{tabular}

* Examined within 1 month of extraction.

+ Corrections for carotenoid pigments have been deducted; the values of these corrections are given in Table 4.

of $\mathrm{FeCl}_{3}$-reducing substances, amounting to $18.8 \%$, was incurred by the saponification procedure in which pyrogallol was omitted. It is of interest to notice the agreement with the data of Lester Smith \& Bailey (1939), who obtained only an $87 \%$ recovery of $\alpha$-tocopherol after saponification of wheat-germ oil in which synthetic $\alpha$-tocopherol was dissolved.

\section{Correction for carotenoid pigments}

Although the quantity of carotenoid pigments is in many cases negligible, a few oils, such as wheatgerm, soya-bean, crude linseed and rape oils contain sufficient quantities of the pigments to necessitate a correction in the total $\mathrm{FeCl}_{3}$-reducing substances. For the determination of a factor which would transform the reducing activity of $\mu \mathrm{g}$. of carotenoid pigments into $\mu \mathrm{g}$. of $\alpha$-tocopherol the following experiment was performed:

$\beta$-Carotene in ethanol in amounts ranging from 0-112 $\mu$ g. was allowed to react with $\mathrm{FeCl}_{3}-\alpha: \alpha^{\prime}$-dipyridyl reagent under conditions identical with those employed in the estimation of vitamin $\mathbf{E}$ and the intensity of the red colour developed was determined colorimetrically. The readings were taken about $20 \mathrm{~min}$. after mixing. The curve relating the concentration of carotene to the extinction coefficient was linear. $1 \mu \mathrm{g}$. of carotene was found to have reducing power equal to $2.5 \mu \mathrm{g}$. of $\alpha$-tocopherol.
In our chromatographic procedure, to be described later, we found that carotene, which is always a small proportion of total carotenoids, passes readily through the column with vitamin E. Xanthophylls, however, remain adsorbed in the column, but can be eluted together with other $\mathrm{FeCl}_{3}$ reducing substances. It is often desirable to estimate the reducing substances other than $\alpha$-tocopherol and carotene. It is then necessary to make a correction for xanthophylls. For this purpose, having no specimen of pure xanthophyll available, we compromised by using the same correction factor of 2.5 as for carotene. The agreement of data in recovery tests before and after chromatographic separation (see later in Tables 8,9 and 11) suggests that the error involved in this procedure is not large.

The correction for carotene is significant in the case of very few natural oils. Correction for xanthophylls found in the 'adsorbed' fraction is large, but. it need be applied only in cases in which recovery of total $\mathrm{FeCl}_{3}$-reducing substances is required. In several freshly extracted natural oils more than traces of carotenoid pigments, as estimated by yellow colour, were present in the unsaponifiable matter. The values of the corrections in the few samples which contained the pigments are given in Table 4. Higher values

Table 4. Correction for carotenoid pigments of some oils

\begin{tabular}{lcc} 
& $\begin{array}{c}\text { Carotenoid pigments } \\
\text { correction } \\
\text { ( } \mu \mathrm{g} \cdot / \mathrm{g} . \text { of oil })\end{array}$ \\
\cline { 2 - 3 } $\begin{array}{c}\text { With } \\
\text { Oil* }\end{array}$ & $\begin{array}{c}\text { Without } \\
\text { pyrogallol }\end{array}$ \\
Wheat-germ & 289 & 271 \\
Soya-bean & 35 & 13 \\
Crude linseed & 30 & 27 \\
Crude rape & 37 & 35 \\
Others & $\begin{array}{c}\text { Traces or no carotenoids } \\
\text { were detected }\end{array}$ \\
* Freshly extracted oils given in Table 3.
\end{tabular}

for total carotenoid pigments were obtained if the oils were saponified in presence of pyrogallol than in its absence. This, therefore, suggests that a small proportion of carotenoid pigments may be destroyed during alkaline saponification and that this can be avoided by using pyrogallol.

\section{Loss of $\mathrm{FeCl}_{3}$-reducing substances on storage of oils}

The values of total $\mathrm{FeCl}_{3}$-reducing substances of some oil samples decreased with the time of storage of the oil. From Table 5, it will be seen that during storage the oils lost a portion of their $\mathrm{FeCl}_{3}$-reducing substances, including carotenoid pigments. The loss was not uniform with all oils, and may depend on the type of oil and the storage conditions. A loss of $17.5 \%$ was incurred in a sample of freshly extracted wheat-germ oil, even when this was stored at a low temperature $\left(2-4^{\circ}\right)$ for a period of only 2 months. It is evident, therefore, that in recording the data for vitamin $E$ it is necessary to give the history of the samples examined. 
Table 5. Loss of $\mathrm{FeCl}_{3}$-reducing substances on storage of oils

Oil
Wheat-germ
Wheat-germ II
Tung
Soya-bean
Crude linseed
Cotton-seed
Crude rape
Crude sesame

Time of examination

1 day after extraction

After storage of 60 days at $2-4^{\circ}$

Over 10 years old

17 months later*

Over 5 years old

15 months later*

Within 1 month of extraction

15 months later*

Within 1 month of extraction

15 months later*

Within 1 month of extraction

15 months later*

Within 1 month of extraction 15 months later*

Within 1 month of extraction 15 months later*

$\mathrm{FeCl}_{3}$-reducing
substances
$(\mu \mathrm{g} \cdot / \mathrm{g}$.
3120
2576
549
491
2370
2039
1356
1222
729
694
696
400
661
440
527
420

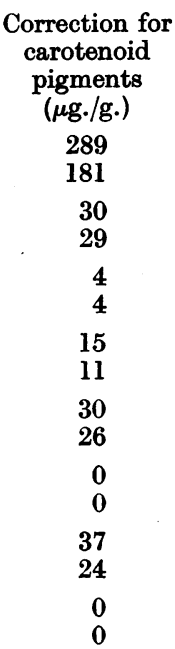

* Stored at room temperature.

\section{The biological inactivity of $\mathrm{FeCl}_{3}$-reducing substances of tung oil}

Tung oil was second only to wheat-germ oil in its content of substances reducing $\mathrm{FeCl}_{3}$ (Tables 2 and 3). Since this oil contained only a small amount of carotenoid pigments (correction being $4 \mu \mathrm{g} . / 1 \mathrm{~g}$. of oil) and no vitamin A, it was necessary to decide whether the rest of $2370 \mu \mathrm{g}$. of the $\mathrm{FeCl}_{3}$ reducing substances/g. of oil was either vitamin $\mathbf{E}$ or 'interfering substances', if it should prove inactive in biological experiments. The unsaponifiable matter of the oil, dissolved in arachis oil, was therefore tested biologically by the method of Evans \& Burr (1927).

The data of these experiments (Table 6) show that total $\mathrm{FeCl}_{3}$-reducing substances of tung oil have very little biological activity. Roughly $80-90 \%$ of the $\mathrm{FeCl}_{3}$-reducing substances are inactive and should be considered as interfering substances in the chemical estimation.

For example, at a dosage of $4.48 \mathrm{mg}$./animal, it was to be expected, if all the $\mathrm{FeCl}_{3}$-reducing substances were $\alpha$-tocopherol, that most of the rats used would have litters. Instead, out of six animals, four showed resorption, only one gave a live litter, whilst one gave a dead litter. In another experiment, ten animals were used and they were dosed with $8.12 \mathrm{mg}$. each. It was thought that the dosage of $8.12 \mathrm{mg}$. of $\mathrm{FeCl}_{3}$-reducing substances should give a $100 \%$ response in biological experiments, even if $\mathrm{FeCl}_{3}$-reduaing substances are present in tung oil in the form of the less biologically active derivatives of tocopherol $(\beta$ - and $\gamma$-tocopherol). But the experiments showed that out of ten animals dosed at this level only one gave a live litter, while in the rest (nine animals) resorption resulted.

\section{Chromatographic separation of biologically inactive $\mathrm{FeCl}_{3}$-reducing substances of tung oil}

The existence of the interfering substances in the unsaponifiable matter of tung oil led to experiments with various chromatographic systems to find suitable conditions for the free passage of $\alpha$-tocopherol with the removal by adsorption of 'interfering' substances.

'Floridin XS earth'-benzene system. With this system we confirmed the findings of Emmerie \& Engel (1939a) that synthetic $\alpha$-tocopherol freely passes through the column with benzene as solvent and eluent. Under such conditions 98.7\% of $\mathrm{FeCl}_{3}$-reducing substances of unsaponifiable matter of tung oil unfortunately behaved in the same way. The 'Floridin XS earth'-benzene system cannot therefore

Table 6. Biological test of unsaponifiable matter of tung oil

\begin{tabular}{|c|c|c|c|c|c|c|}
\hline & Date of exp. & $\begin{array}{c}\text { Dose of } \mathrm{FeCl}_{3}- \\
\text { reducing } \\
\text { substances } \\
\text { (mg./animal) }\end{array}$ & $\begin{array}{l}\text { No. of } \\
\text { animals }\end{array}$ & Resorption & $\begin{array}{c}\text { Dead } \\
\text { litters }\end{array}$ & $\begin{array}{c}\text { Live } \\
\text { litters }\end{array}$ \\
\hline $\begin{array}{l}\text { arachis } \\
\text { (control) } \\
\text { arachis } \\
\text { (control) }\end{array}$ & $\begin{array}{c}\text { June } 1943 \\
\text {," } \\
\text { August } 1943 \\
,,\end{array}$ & $\begin{array}{r}4.48 \\
0.08 \\
8.12 \\
0.08\end{array}$ & $\begin{array}{r}6 \\
5 \\
10 \\
3\end{array}$ & $\begin{array}{l}4 \\
5 \\
9 \\
3\end{array}$ & $\begin{array}{l}1(1)^{*} \\
0 \\
0 \\
0\end{array}$ & $\begin{array}{l}1(1)^{*} \\
0 \\
1(4)^{*} \\
0\end{array}$ \\
\hline
\end{tabular}

* Figures in brackets denote the number of animals in each litter.

* Tung in arachis Arachis (control) Arachis (control) 
be used for the separation of $\alpha$-tocopherol from the biologically inactive 'interfering substances' in tung oil.

Aluminium oxide-light petroleum + ethanol system. In our experience aluminium oxide, if left exposed to air, adsorbs moisture, and its adsorption activity is reduced. For the purpose of eliminating this trouble, we have used several brands of standard activated aluminium oxide which exhibited constant adsorption properties. Further, it was found that with any standard $\mathrm{Al}_{2} \mathrm{O}_{3}$ the adsorption activity was reduced with an increased concentration of ethanol added to light petroleum, which served as solvent and eluent. The degree of adsorption of synthetic $\alpha$-tocopherol, as well as of other $\mathrm{FeCl}_{3}$-reducing substances on aluminium oxide, will therefore depend inter alia on both these factors.

For more detailed study of this system the chromatographic procedure was standardized. The alumina was activated by heating in a hot-air oven at $100^{\circ}$ for $2-3 \mathrm{hr}$., just before preparing the column, which was $50 \mathrm{~mm}$. long by $10 \mathrm{~mm}$. diameter. As solvent light petroleum A.R. (b.p. $40-60^{\circ}$ ) was used, with the addition of 0.0-1.5\% ethanol, depending on the experiment. $10 \mathrm{ml}$. of solvent were used for preparing the column, $5 \mathrm{ml}$. for dissolving $\alpha$-tocopherol or the $\mathrm{FeCl}_{3}$-reducing substances, and $15 \mathrm{ml}$. for subsequent washing of the column. The solvent was always added before the top of the column became dry. The filtration rate was 70-90 drops/min.

The latter procedure was successful when activated aluminium oxide (British Drug Houses Ltd.) was used in combination with light petroleum and $1.0 \%$ ethanol. After the preliminary experiments the adsorption activity of this alumina was studied in relation to the concentration of ethanol added to light petroleum. Table $7 a$ shows that $\alpha$-tocopherol was quantitatively adsorbed by the column if the concentration of ethanol in the solvent ranges between $0-0.40 \%$. With ethanol concentrations ranging between $0.60-0.90 \%$ there was partial recovery, and with $1.0 \%$ or over a quantitative recovery. With $1 \%$ ethanol the standard column gave quantitative recoveries with $173-1734 \mu \mathrm{g}$. of $\alpha$-tocopherol.

When the $\mathrm{FeCl}_{3}$-reducing substances of the unsaponifiable matter of tung oil are passed through this column, and the solvent used contained $1 \%$ of ethanol, $21 \cdot 3 \%$ of these are found in the unadsorbed fraction. The adsorbed substances could be eluted with $10 \mathrm{ml}$. of light petroleum containing $20 \%$ ethanol, and amounted to $75 \cdot 7 \%$ of the total $\mathrm{FeCl}_{3}$ reducing substances found in control samples before chromatographic analysis. The total recovery after chromatographic separation therefore amounted to $\mathbf{9 7 \cdot 0} \%$.

The necessity of selecting the correct brand of aluminium oxide is emphasized by our failure with two other preparations. A specimen made by Brockman's method adsorbed too strongly, and failed to allow the quantitative passage of $\alpha$-tocopherol even at concentrations of ethanol which allow the passage of the 'interfering substances' of tung oil. A specimen from A. Wander Ltd. adsorbed weakly (Table 7b), and allowed a passage through the column of about $70 \%$ of the 'interfering substances', at $0.8 \%$ concentration of ethanol.
Table 7. Adsorption and recovery of $\alpha$-tocopherol

Aluminium oxide-light petroleum-ethanol system

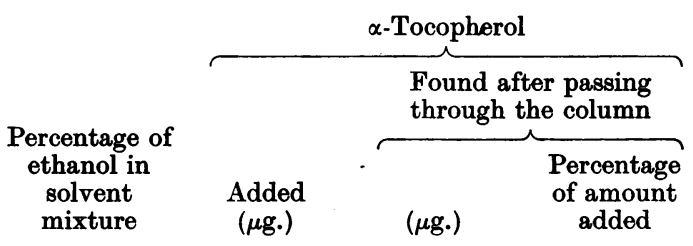

(a) 'B.D.H.' aluminium oxide for chromatographic analysis

$\begin{array}{rrrr}0.00 & 867 & 0 & 0 \\ 0 \cdot 40 & 867 & 0 & 0 \\ 0.60 & 867 & 127 & 14 \cdot 7 \\ 0 \cdot 70 & 867 & 533 & 61 \cdot 6 \\ 0 \cdot 80 & 867 & 617 & 70 \cdot 5 \\ 0.90 & 867 & 834 & 96 \cdot 3 \\ 1.00 & 1734 & 1725 & 99 \cdot 6 \\ 1 \cdot 00 & 867 & 867 & 100 \cdot 0 \\ 1 \cdot 00 & 867 & 859 & 99 \cdot 2 \\ 1.00 & 173 & 172 & 99 \cdot 5 \\ 1 \cdot 20 & 867 & 867 & 100 \cdot 0\end{array}$

(b) Aluminium oxide (A. Wander Ltd.)

$\begin{array}{lrrr}0.00 & 867 & 0 & 0 \\ 0.30 & 867 & 64 & \mathbf{7 \cdot 4} \\ 0 \cdot 45 & 867 & 513 & 59 \cdot 2 \\ 0 \cdot 60 & 867 & 681 & \mathbf{7 8 \cdot 5} \\ 0.70 & 867 & \mathbf{7 8 4} & \mathbf{9 0 \cdot 4} \\ 0.80 & 867 & 867 & 100 \cdot 0 \\ 0.90 & 867 & 874 & 100 \cdot 8 \\ 1 \cdot 00 & 867 & 862 & 99 \cdot 3\end{array}$

Inftuence of $\alpha$-tocopherol on the adsorption of $\mathrm{FeCl}_{3}$ reducing substances of some oils, and the influence of the latter on the passage of $\alpha$-tocopherol

Although the technique described in the preceding section seemed promising it remained to be decided (a) whether the column can separate the interfering substances of oils other than tung oil in presence and absence of synthetic $\alpha$-tocopherol, and (b) whether the relative concentration of $\alpha$-tocopherol to that of other reducing substances has any effect.

To test the influence of synthetic $\alpha$-tocopherol on the behaviour of the mixed reducing substances of plant oils, wheat-germ oil, crude cotton-seed oil, and tung oil were chosen as three widely different types which contain large quantities of reducing substances. Mixtures were prepared containing about the same quantities of $\alpha$-tocopherol and of the reducing substances present in the unsaponifiable matter of each oil. Each mixture was then passed through a column. The 'unadsorbed' fraction and an 'adsorbed' fraction, which was eluted with $10 \mathrm{ml}$. of light petroleum containing $20 \%$ ethanol, were collected separately. For each test, control experiments were done with separate constituents of each system without mixing.

$\alpha$-Tocopherol and the unsaponifiable matter of oils were adsorbed to the same extent whether passed through the column separately or as mixtures (Table 8). The 'adsorbed' and 'unadsorbed' fractions, moreover, showed little change in their 
Table 8. Influence of synthetic $\alpha$-tocopherol on the passage, through alumina columns, of $\mathrm{FeCl}_{3}$-reducing substances of unsaponifiable matter of some oils

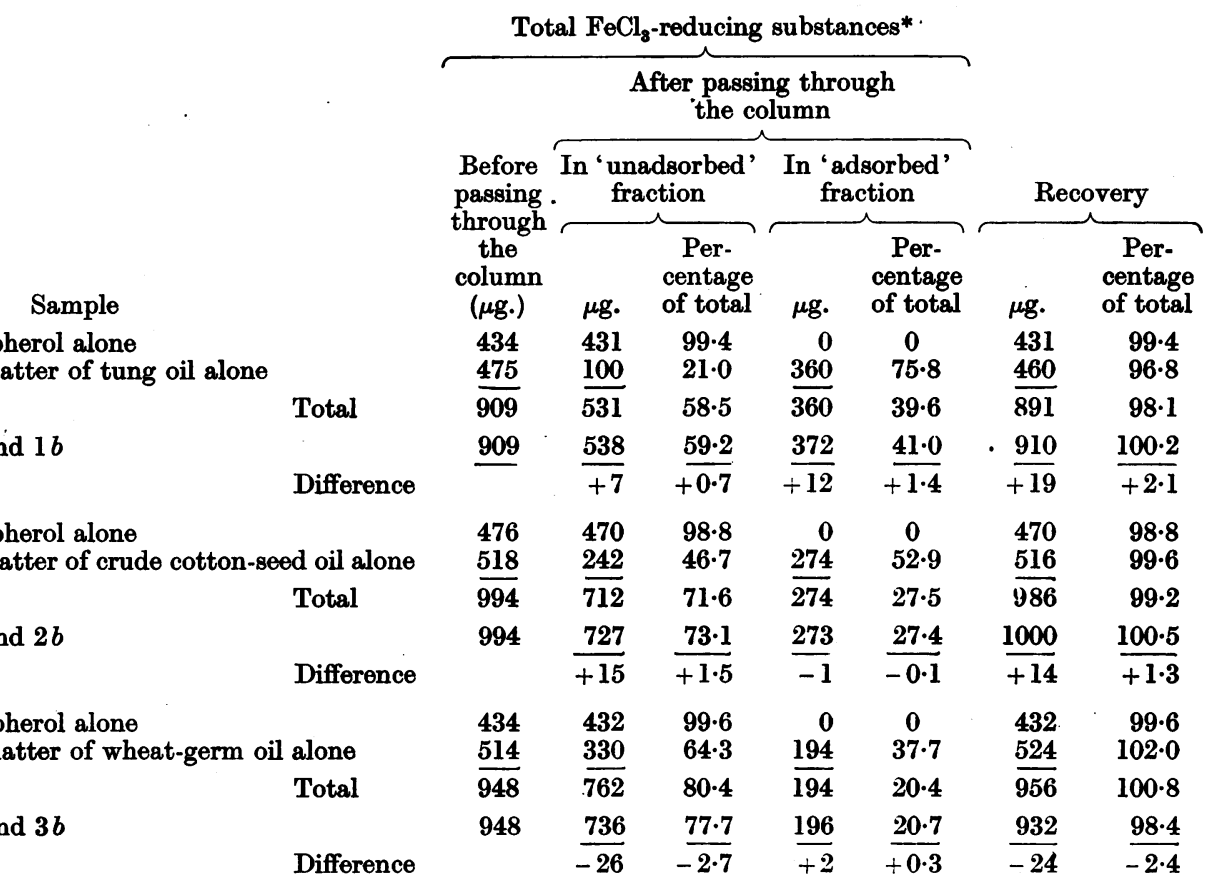

la Synthetic $\alpha$-tocopherol alone

$1 b$ Unsaponifiable matter of tung oil alone

I. Mixture of $1 a$ and $1 b$

* Correction for carotenoid pigments deducted.

$2 a$ Synthetic $\alpha$-tocopherol alone

$2 b$ Unsaponifiable matter of crude cotton-seed oil alone

II. Mixture of $2 a$ and $2 b$

$3 a$ Synthetic $\alpha$-tocopherol alone

$3 b$ Unsaponifiable matter of wheat-germ oil alone

III. Mixture of $3 a$ and $3 b$

Table 9. Recovery of synthetic $\alpha$-tocopherol in presence of unsaponifiable substances of wheat-germ oil

Total $\mathrm{FeCl}_{\mathbf{3}}$-reducing suibstances*

\section{Sample}

la Synthetic $\alpha$-tocopherol alone

$1 b$ Unsaponifiable fraction of wheat-germ oil alone

Total

I. Mixture of $1 a$ and $1 b$

Difference

$2 a$ Synthetic $\alpha$-tocopherol alone

$2 b$ Unsaponifiable fraction of wheat-germ oil alone

Total

II. Mixture of $2 a$ and $2 b$

\section{Difference}

$3 a$ Synthetic $\alpha$-tocopherol alone

$3 b$ Unsaponifiable fraction of wheat-germ oil alone

Total

III. Mixture of $3 a$ and $3 b$

\begin{tabular}{|c|c|c|c|c|c|c|}
\hline \multirow{4}{*}{$\begin{array}{l}\text { Before } \\
\text { passing } \\
\text { through } \\
\text { the } \\
\text { column } \\
(\mu \mathrm{g} .) \\
434 \\
1028\end{array}$} & \multicolumn{4}{|c|}{$\begin{array}{l}\text { After passing through } \\
\text { the column }\end{array}$} & & \\
\hline & \multicolumn{2}{|c|}{$\begin{array}{l}\text { In 'unadsorbed' } \\
\text { fraction }\end{array}$} & \multicolumn{2}{|c|}{$\begin{array}{l}\text { In 'adsorbed' } \\
\text { fraction }\end{array}$} & \multicolumn{2}{|c|}{ Recovery } \\
\hline & $\mu \mathrm{g}$. & $\begin{array}{l}\text { Per- } \\
\text { centage } \\
\text { of total }\end{array}$ & $\mu \mathrm{g}$. & $\begin{array}{c}\text { Per- } \\
\text { centage } \\
\text { of total }\end{array}$ & $\mu \mathrm{g}$ & $\begin{array}{c}\text { Per- } \\
\text { centage } \\
\text { of total }\end{array}$ \\
\hline & $\begin{array}{l}432 \\
628 \\
\end{array}$ & $\begin{array}{l}99 \cdot 6 \\
61 \cdot 1\end{array}$ & $\begin{array}{r}0 \\
401 \\
\end{array}$ & $\begin{array}{c}0 \\
39 \cdot 0\end{array}$ & $\begin{array}{r}432 \\
1029 \\
\end{array}$ & $\begin{array}{r}99 \cdot 6 \\
100 \cdot 1\end{array}$ \\
\hline 1462 & 1060 & $72 \cdot 6$ & 401 & $27 \cdot 4$ & 1461 & $100 \cdot 0$ \\
\hline \multirow[t]{2}{*}{1462} & 1034 & $70 \cdot 8$ & 395 & $27 \cdot 0$ & 1429 & $97 \cdot 8$ \\
\hline & -26 & $-1 \cdot 8$ & -6 & -0.4 & -32 & $-2 \cdot 2$ \\
\hline $\begin{array}{l}434 \\
514\end{array}$ & $\begin{array}{l}432 \\
330 \\
\end{array}$ & $\begin{array}{l}99 \cdot 6 \\
64 \cdot 3\end{array}$ & $\begin{array}{r}0 \\
194 \\
\end{array}$ & $\begin{array}{c}0 \\
\mathbf{3 7} \cdot \mathbf{7}\end{array}$ & $\begin{array}{l}432 \\
524\end{array}$ & $\begin{array}{r}99 \cdot 6 \\
102 \cdot 0\end{array}$ \\
\hline 948 & 762 & $80 \cdot 4$ & 194 & $20 \cdot 4$ & $\overline{956}$ & $100 \cdot 8$ \\
\hline \multirow[t]{2}{*}{948} & 736 & $77 \cdot 7$ & 196 & $20 \cdot 7$ & 932 & $98 \cdot 4$ \\
\hline & -26 & $-2 \cdot 7$ & +2 & +0.3 & $\overline{-24}$ & $-2 \cdot 4$ \\
\hline $\begin{array}{l}434 \\
257\end{array}$ & $\begin{array}{l}432 \\
151\end{array}$ & $\begin{array}{l}99 \cdot 6 \\
58 \cdot 9\end{array}$ & $\begin{array}{r}0 \\
95\end{array}$ & $\begin{array}{c}0 \\
\mathbf{3 7 \cdot 0}\end{array}$ & $\begin{array}{l}432 \\
246\end{array}$ & $\begin{array}{l}99 \cdot 6 \\
95 \cdot 9\end{array}$ \\
\hline 691 & 583 & $84 \cdot 3$ & 95 & $13 \cdot 7$ & 678 & $98 \cdot 1$ \\
\hline \multirow[t]{2}{*}{691} & 579 & $83 \cdot 8$ & 117 & 16.9 & 696 & $100 \cdot 7$ \\
\hline & -4 & -0.5 & +22 & $+3 \cdot 2$ & +18 & $+2 \cdot 6$ \\
\hline
\end{tabular}

\footnotetext{
* Correction for carotenoid pigments deducted.
} 
adsorptive properties when passed through the column for the second time. The ratio $6 f \alpha$-tocopherol to other reducing substances was also without effect on their chromatographic separation (Table 9). With our standardized column consistent results were obtained with amounts of total $\mathrm{FeCl}_{3}$-reducing substances from 257 to $1462 \mu \mathrm{g}$.

\section{Biological activity of the two fractions of wheat-germ oil}

The unsaponifiable matter of wheat-germ oil (Table 8) contained some $40 \%$ of reducing substances which were adsorbed on the column, and hence did not appear to be $\alpha$-tocopherol. To confirm this conclusion biological tests were carried out upon the adsorbed and unadsorbed fractions.

Freshly extracted wheat-germ oil was saponified in presence of pyrogallol and the unsaponifiable matter was dissolved in sufficient light petroleum $+1.0 \%$ ethanol, so that $5 \mathrm{ml}$. of this solution contained about $1 \mathrm{mg}$. of $\mathrm{FeCl}_{3}-$ reducing substances. $5 \mathrm{ml}$. portions of this solution were chromatographically separated, each portion with a freshly made column. The unadsorbed fractions were combined, the solvent evaporated under reduced pressure and the unsaponifiable matter obtained in this way was dissolved in a suitable volume of arachis oil. Each adsorbed fraction ,was eluted from the column with $10 \mathrm{ml}$. portions of light petroleum containing $20 \%$ ethanol, and the eluates combined and evaporated under reduced pre re. The unadsorbed fraction obtained in this way i... iso dissolved in arachis oil. Before dosing, the redv substances of the two preparations were estimated chemically.

The two fractions were tested biologically, as described earlier, against arachis oil as a control (Table 10). Treatment with the adsorbed fraction, at the dosage of $3.5 \mathrm{mg}$. of reducing substances after correction for cárotenoid pigments, tocopherols. Reducing substances which remain adsorbed in the column are either not tocopherol or are modifications of tocopherol which have only slight biological activity. This view is consistent with our previous finding that the reducing substances of tung oil which are mainly adsorbed on the column, show only slight activity in biological tests.

\section{Method FOR THE CHEMICAL ESTIMATION OF VITAMTN E \\ Reagents}

Pyrogallol solution. 5\% (w/v) freshly prepared, with ethanol as solvent.

$\mathrm{KOH}$ solution (for saponification). Aqueous solution containing $4 \mathrm{~g}$. of $\mathrm{KOH}+2 \cdot 7 \mathrm{ml} . \mathrm{H}_{2} \mathrm{O}$.

$\alpha$-Tocopherol standard (for calibration purposes). Ethanol solution containing about $1 \mathrm{mg}$. of synthetic $\alpha$-tocopherol/ $1 \mathrm{ml}$.

$\mathrm{FeCl}_{3}$ solution. Freshly prepared $0 \cdot 2 \%(w / v)$ ethanol solution.

$\alpha: \alpha^{\prime}-$ Dipyridyl solution. Freshly prepared $0.5 \%(\mathrm{w} / \mathrm{v})$ ethanol solution. This reagent, and the $\mathrm{FeCl}_{3}$, may be stored in the dark for over 2 weeks.

Ethyl ether. A.R. for extraction purposes.

Ethanol. A.R.

Light petroleum. A.R. (b.p. 40-60 ${ }^{\circ}$.

Aluminium oxide (British Drug Houses Ltd., for chromatographic analysis). Activated by heating at $100^{\circ}$ in an air oven for 2-3 hr. before use. It is essential to standardize each new batch of alumina against known materials, such as synthetic $\alpha$-tocopherol and the unsaponifiable matter of tung oil.

Light petroleum + ethanol solvent. For chromatography, $1 \%(v / v)$ of absolute ethanol in petroleum ether; for eluting the 'adsorbed fraction' $20 \%(\mathrm{v} / \mathrm{v})$ ethanol in petroleum ether.

Table 10. Biological test of 'adsorbed' and 'unadsorbed' fractions of unsaponifiable matter of wheat-germ oil

\begin{tabular}{|c|c|c|c|c|c|c|}
\hline Sample & Date of exp. & $\begin{array}{c}\text { Dose of } \mathrm{FeCl}_{3}- \\
\text { reducing } \\
\text { substances } \\
\text { (mg./animal) }\end{array}$ & $\begin{array}{l}\text { No. of } \\
\text { animals }\end{array}$ & Resorption & $\begin{array}{c}\text { Dead } \\
\text { litters }\end{array}$ & $\begin{array}{l}\text { Live } \\
\text { litters }\end{array}$ \\
\hline $\begin{array}{l}\text { Adsorbed fraction dis- } \\
\text { solved in arachis oil }\end{array}$ & May 1944 & $3 \cdot 50$ & 5 & 5 & 0 & 0 \\
\hline $\begin{array}{l}\text { Unadsorbed fraction dis- } \\
\text { solved in arachis oil }\end{array}$ & $"$ & $4 \cdot 00$ & 7 & 2 or 3 & 1 or 2 & (7) $\stackrel{3}{(7)}(2)^{*}$ \\
\hline Arachis oil (control) & ", & $0 \cdot 18$ & 5 & 5 & 0 & 0 \\
\hline
\end{tabular}

gave no response in any of the five rats which were used. Resorption resulted in all cases. On the other hand, animals which were dosed with $4 \mathrm{mg}$. of $\mathrm{FeCl}_{3}$-reducing substances from the unadsorbed fraction gave litters, with the exception of two animals in which resorption occurred. The controls, dosed with arachis oil only, gave no response, as resorption occurred in all of five animals.

Our experiments, therefore, support the conclusion that reducing substances which appear in the unadsorbed fraction of wheat-germ oil are mainly

\section{Procedure}

Saponification. $1 \mathrm{~g}$. of oil is weighed in a conical flask, $2 \mathrm{ml}$. of $5 \%$ pyrogallol are added, and the mixture is heated to $86^{\circ}$ on a water-bath. After the addition of $0.44 \mathrm{ml}$. of the $\mathrm{KOH}$ solution, the flask is shaken in the bath for about 2 min., which usually causes complete saponification. To the mixture $8 \mathrm{ml}$. distilled water are added, the unsaponifiable matter is extracted in a separating funnel by shaking vigorously first with $10 \mathrm{ml}$. of ether and then with $5 \mathrm{ml}$. of ether. The two ether extracts are combined and washed 
The Chemical Estimation of Vitamin $\mathbf{E}$ in Vegetable Oils. By J. Tošić \& T. Moore

Volume 39 (1945), No. 5, p. 504, col. 2, line 2 from bottom for $5 \mathrm{ml}$. read $15 \mathrm{ml}$. 
twice, each time with $5 \mathrm{ml}$. of $0.5 \%$ aqueous $\mathrm{KOH}$, vigorous shaking being avoided at this stage in view of the danger of emulsions. The ether extract is next washed several times with $10 \mathrm{ml}$. portions of distilled water, with only gentle shaking for the first and second times. Adequate washing of the extract is indicated by the quick separation of layers after vigorous shaking. The ether extract is evaporated on a water-bath, under reduced pressure, and the unsaponifiable matter dissolved in a volume. $f$ ethanol, so that 1 or $2 \mathrm{ml}$. of such solution are equivalent to about $1 \mathrm{mg}$. of $\mathrm{FeCl}_{3}$-reducing substances. The solution at this stage may be kept overnight in a refrigerator without harm.

If duplicate estimations are to be made, unsaponifiable matter equivalent to $2400-4000 \mu \mathrm{g}$. of reducing substances should be prepared. It is usually necessary to take more than $1 \mathrm{~g}$. of oil, to increase proportionately the amounts of all the reagents used, and sometimes to extend slightly the time of saponification.

Chromatographic analysis. A portion of the solution of unsaponifiable matter, containing about $1 \mathrm{mg}$. of the reducing substances, is evaporated under reduced pressure to dryness on a hot water-bath, and care is taken to remove all ethanol. (a) Solvent. $30 \mathrm{ml}$. of light petroleum $+1 \%$ ethanol solvent are prepared carefully for each chromatographic separation. (b) Preparation of aluminium oxide column. Activated aluminium oxide is packed in a tube of $10 \mathrm{~mm}$. diameter and about $120 \mathrm{~mm}$. long, so that length of the column is $50 \mathrm{~mm}$. and diameter $10 \mathrm{~mm} .10 \mathrm{ml}$. of light petroleum ether $+1 \%$ ethanol solvent are passed through the column, which is now ready for use. For each estimation a new column should be made.

A portion of the unsaponifiable matter is dissolved in $5 \mathrm{ml}$. of the solvent mixture and passed through the column which is then washed with $15 \mathrm{ml}$. of the solvent. Throughout the analysis the top of the column should not be allowed to become dry, and the rate of filtration should be 70-90 drops/min. The 'unadsorbed fraction' of $20 \mathrm{ml}$. volume is collected in a clean flask, the solvent evaporated under reduced pressure on a' hot water-bath, and the residue dissolved in ethanol and made up to a volume of not more than $25 \mathrm{ml}$. This solution is now ready for colorimetric estimations.

Colorimetric estimations. (a) Estimation of carotenoid pigments. In the unadsorbed fraction mainly carotene is found, and is estimated by its natural yellow colour by means of a Pulfrich photometer with the $\mathrm{S} 47$ filter. The quantity of carotene is expressed in $\mu \mathrm{g} . / \mathrm{l}$ g. of oil. (b) Estimation of vitamin $E$. A portion of the solution, containing between 100 and $160 \mu \mathrm{g}$. of $\mathrm{FeCl}_{3}$-reducing substances, is pipetted out into a $25 \mathrm{ml}$. measuring flask. This is found out in a preliminary test, if the vitamin $\mathbf{E}$ content of the material examined is quite unknown. Sufficient ethanol is added to bring the volume to about $20 \mathrm{ml}$, then $1 \mathrm{ml}$. of $\mathrm{FeCl}_{3}$ solution followed by $1 \mathrm{ml}$. of $\alpha: \alpha^{\prime}$-dipyridyl solution. The volume is then made up to $25 \mathrm{ml}$. with ethanol, the contents being mixed by shaking the flasks after each addition. The control is prepared in the same way, but the unsaponifiable matter is omitted. The flasks are left in a dark place for $15 \mathrm{~min}$. for full development of the colour. The unknown and the control solutions are transferred to $5 \mathrm{~cm}$. long micro-cells, and their colours matched in a Pulfrich photometer with the use of the green S53 filter. Since the solutions are sensitive to light the measurements must be made in diffused daylight or low artificial illumination.
Calculation of results. As an example, results with a sample of soya-bean oil may be quoted. $4 \cdot 14 \mathrm{~g}$. of oil were saponified, and the unsaponifiable matter dissolved in $4 \cdot 14 \mathrm{ml}$. of ethanol. $1 \mathrm{ml}$. portions of this solution were chromatographed. The unadsorbed fraction containing vitamin $\mathbf{E}$ was eventually brought up to the volume of $20 \mathrm{ml}$. and carotene and vitamin $\mathbf{E}$ content of oil estimated.

Uncorrected vitamin $E$ value. $6 \mathrm{ml}$. of this solution gave an extinction reading of 0.47 , so that $\mathrm{FeCl}_{3}$-reducing substances of this fraction amount to $0.47 \times 166.6 \times \frac{20}{6}=261 \mu \mathrm{g}$. $1 \mathrm{~g}$. oil. The factor 166.6 converts the step photometer reading into $\mu \mathrm{g}$. of $\alpha$-tocopherol (see p. 499).

Carotene correction. It was found that $1 \mathrm{~g}$. of oil contained $1 \cdot 17 \mu \mathrm{g}$. of carotene; thus the correction for this pigment amounts to $2 \cdot 9 \mu \mathrm{g} . / 1 \mathrm{~g}$. of oil (see p. 500).

Vitamin $E$. After the carotene correction is deducted, the vitamin $\mathrm{E}$ content of the oil comes to $258 \mu \mathrm{g} . / 1 \mathrm{~g}$. of 'apparent' $\alpha$-tocopherol.

Estimation of the reducing substances of the 'adsorbed' fraction and of total $\mathrm{FeCl}_{3}$-reducing substances. Although these substances are discarded in the estimation of vita$\min \mathrm{E}$, their evaluation is recommended for two reasons. First, if an estimation is also made of the total reducing substances of the unsaponifiable fraction before chromatographing, a useful check is available on the recovery of reducing substances, and on the behaviour of the adsorption column. Secondly, a high proportion of adsorbed reducing substances may suggest the desirability of biological tests for tocopherol isomers other than the $\alpha$-form. These isomers, which may be more strongly adsorbed, have low biological activity.

The adsorbed substances are eluted from the adsorption column with $10 \mathrm{ml}$. of light petroleum containing $20 \%$ ethanol, and estimations are made of the yellow colour and of $\mathrm{FeCl}_{3}$-reducing substances in a similar way to that described for carotene and vitamin $\mathrm{E}$.

\section{Vitamin $E$ content of oils}

The contents of vitamin $\mathbf{E}$ and of reducing substances other than vitamin $E$ of numerous vegetable oils are recorded in Table 11. Wheat-germ oil, in which vitamin $E$ made up $60 \%$ of the total reducing substances, was the richest source. Some other oils, e.g. tung oil, soya-bean oil, contained relatively large quantities of reducing substances, but only about $20 \%$ of these were in the form of vitamin $\mathrm{E}$. An old specimen of crude cotton-seed oil, a recognized source of vitamin $\mathrm{E}$, contained about one-third of the total reducing substances of fresh wheat-germ oil, and $45 \%$ appeared to be $\alpha$-tocopherol. Coconut oil and palm-kernel oil contained no reducing substances.

\section{Tocopherol isomers}

The presence in natural fats of the $\beta$-and $\gamma$-isomers of tocopherol, and possibly also of other substances having slight vitamin $\mathbf{E}$ activity, raises a problem which we have been unable to investigate fully, mainly on account of difficulties in obtaining the isomers in this country. Through the kindness of Prof. A. R. Todd, however, we obtained a small 
Table 11. Vitamin $E$ and other $\mathrm{FeCl}_{3}$-reducing substances of plant oils

\begin{tabular}{|c|c|c|c|c|c|c|c|c|}
\hline \multirow{3}{*}{$\cdot$} & \multirow{4}{*}{$\begin{array}{c}\text { Time of } \\
\text { examination } \\
\text { after } \\
\text { extraction } \\
\text { (months) }\end{array}$} & \multicolumn{5}{|c|}{$\mathrm{FeCl}_{3}$-reducing substances } & \multicolumn{2}{|l|}{ · } \\
\hline & & \multirow{3}{*}{$\begin{array}{c}\text { Before } \\
\text { passing } \\
\text { through } \\
\text { the } \\
\text { column } \\
\text { ( } \mu \mathrm{g} \cdot / \mathrm{g} . \\
\text { of oil) }\end{array}$} & \multicolumn{4}{|c|}{ After chromatographic separation } & & \\
\hline & & & \multicolumn{2}{|c|}{$\begin{array}{c}\text { In 'unadsorbed' } \\
\text { fraction* }\end{array}$} & \multicolumn{2}{|c|}{$\begin{array}{c}\text { In 'adsorbed' } \\
\text { fraction }\end{array}$} & \multicolumn{2}{|c|}{ Recovery } \\
\hline Oil & & & $\begin{array}{l}\mu \mathrm{g} \cdot / \mathrm{g} . \\
\text { of oil }\end{array}$ & $\begin{array}{c}\text { Percentage } \\
\text { of total }\end{array}$ & $\begin{array}{l}\mu \mathrm{g} . / \mathrm{g} . \\
\text { of oil }\end{array}$ & $\begin{array}{c}\text { Percentage } \\
\text { of total }\end{array}$ & $\begin{array}{l}\mu \mathrm{g} \cdot / \mathrm{g} . \\
\text { of oil }\end{array}$ & $\begin{array}{c}\text { Percentage } \\
\text { of total }\end{array}$ \\
\hline Wheat-germ I & Within 2 & $2776 \dagger$ & $1690 \dagger$ & $60 \cdot 9$ & $1061 \dagger$ & $38 \cdot 2$ & $2751 \dagger$ & $99 \cdot 1$ \\
\hline Wheat-germ II & Over 144 & $491 \dagger$ & $286 \dagger$ & $58 \cdot 3$ & $160 \dagger$ & $32 \cdot 6$ & $491 \dagger$ & $92 \cdot 0$ \\
\hline Tung & Over 84 & $2039 \dagger$ & $444 \dagger$ & $21 \cdot 8$ & 1540 & $75 \cdot 6$ & $1984 \dagger$ & $97 \cdot 4$ \\
\hline Soya-bean & 15 & $1222 \dagger$ & $250 \dagger$ & $20 \cdot 5$ & $967 \dagger$ & $79 \cdot 3$ & $1217 \dagger$ & $99 \cdot 8$ \\
\hline Cotton-seed (crude) & Over 84 & $936 \dagger$ & $425 \dagger$ & $45 \cdot 4$ & 497† & $53 \cdot 1$ & 922 & $98 \cdot 5$ \\
\hline Cotton-seed (refined) & 15 & 400 & 144 & $36 \cdot 0$ & 254 & $63 \cdot 5$ & 398 & $99 \cdot 5$ \\
\hline First castor & 15 & 693 & 184 & $26 \cdot 5$ & 493 & $71 \cdot 2$ & 677 & $97 \cdot 7$ \\
\hline Linseed (crude) & 15 & $694 \dagger$ & $110 \dagger$ & $15 \cdot 8$ & $578 \dagger$ & $83 \cdot 3$ & $688 \dagger$ & $99 \cdot 1$ \\
\hline Maize & Over 84 & 458 & 274 & $59 \cdot 8$ & 168 & $36 \cdot 7$ & 442 & $96 \cdot 5$ \\
\hline Rape (crude) & 15 & $440 \dagger$ & $110 \dagger$ & $25 \cdot 0$ & 331† & $75 \cdot 2$ & $\mathbf{4 4 1 \dagger}$ & $100 \cdot 2$ \\
\hline Sesame & 15 & $420^{\circ}$ & 40 & $9 \cdot 5$ & 359 & 85.5 & 399 & $95 \cdot 0$ \\
\hline Arachis I & 15 & 336 & 125 & $37 \cdot 2$ & 212 & $63 \cdot 1$ & 337 & $100 \cdot 3$ \\
\hline Arachis II & 15 & 240 & 108 & $45 \cdot 0$ & 128 & $53 \cdot 3$ & 236 & $98 \cdot 3$ \\
\hline Cocoa-butter (crude) & 15 & 212 & 47 & $22 \cdot 2$ & 156 & $73 \cdot 6$ & 203 & $95 \cdot 8$ \\
\hline Arachis III & 15 & 123 & 39 & $31 \cdot 7$ & 81 & $65 \cdot 8$ & 120 & $97 \cdot 5$ \\
\hline Coconut & 15 & 0 & $\mathbf{0}$ & 一 & $\mathbf{0}$ & - & - & - \\
\hline Palm-kernel & 15 & $\mathbf{0}$ & $\mathbf{0}$ & - & 0 & - & - & - \\
\hline
\end{tabular}

* Vitamin E fraction.

$\dagger$ Correction for carotenoid pigments has been deducted from the figures marked with asterisk; other oils contained either traces or no carotenoid pigments.

$\ddagger$ A sample of refined undeodorized ground-nut oil for special white margarine.

specimen of the $p$-nitrophenyl-urethane of $\beta$-tocopherol. After saponification the free alcohol was run on to the adsorption column in the usual way. In contrast to the behaviour of the $\alpha$-isomer only some $30 \%$ passed through.

Further investigation into the separation of the tocopherol isomers is obviously desirable. It is fortunate, however, that the inefficient passage of $\beta$-tocopherol through the column, if confirmed, tends to compensate for its much lower biological activity, which according to Mason (1944) is only $40 \%$ of that of $\alpha$-tocopherol. As far as the $\alpha$ - and $\beta$-isomers are concerned, therefore, our routine method should give a good indication of the total biological activity, as usually expressed in terms of $\alpha$-tocopherol.

\section{SUMMARY}

1. A method based on the $\alpha: \alpha^{\prime}$-dipyridyl- $\mathrm{FeCl}_{3}$ reaction has been evolved for the estimation of vitamin $E$ in vegetable oils.

2. To avoid oxidation of the vitamin and other $\mathrm{FeCl}_{3}$-reducing substances, the oils have been saponified in the presence of pyrogallol.

3. In addition to the known interference by carotenoid pigments, it has been found that the unsaponifiable fractions always contain varying amounts of other irrelevant substances which are capable of reducing $\mathrm{FeCl}_{3}$. These are presumably of low or negligible biological activity, and have been removed by adsorption on a column of activated alumina, under conditions which were carefully adjusted to allow the free passage of $\alpha$-tocopherol.

4. Values for vitamin $E$, 'total reducing substances' and the interfering substances have been estimated for many oils. Tung oil gave a high value for total reducing substances, but only $20 \%$ appeared to be in the ' $\alpha$-tocopherol fraction', and the biological activity of the unsaponifiable fraction as a whole was correspondingly poor. In wheat-germ oil the ' $\alpha$-tocopherol fraction' represented some $60 \%$ of the total reducing substances. Biological tests were consistent with the concentration of activity in this fraction, and its absence from the remaining $40 \%$ of reducing substances, which were separated by the adsorption column.

5. Further investigation into the separation of tocopherol isomers is obviously desirable. In our method $\beta$-tocopherol is partially adsorbed on the column. In practice, however, this inefficient passage through the column tends to compensate for its much lower biological activity.

Our thanks are due to Dr L. J. Harris for his valuable criticisms and to Miss A. C. Cooper for care of the experimental animals. 


\title{
REFERENCES
}

British Pharmaceutical Codex (1942), 3rd suppl. p. 73.

Drummond, J. C., Singer, E. \& MacWalter, R. J. (1935). Biochem. J. 29, 2510.

Emmerie, A. \& Engel, C. (1938). Rec. trav. chim. Pays-Bas, $57,1351$.

Emmerie, A. \& Engel, C. (1939a). Rec.trav. chim. Pays-Bas, $58,283$.

Emmerie, A. \& Engel, C. (1939 b). Rec.trav. chim. Pays-Bas, $58,895$.

Evans, H. M. \& Burr, G. O. (1927). Mem. Univ. Calif. no. 8. Furter, M. \& Meyer, R. E. (1939). Helv. chim. Acta, 22, 240.
Karrer, P. \& Keller, H. (1938). Helv. chim. Acta, 21, 1234.

Karrer, P. \& Keller, H. (1939). Helv. chim. Acta, 22, 260.

Kaunitz, H. (1944). J. biol. Chem. 156, 661.

Lester Smith, E. \& Bailey, R. (1939). Vitamin E, A Symposium, p. 21. Cambridge: Heffer.

Mason, K. E. (1944). Vitamins and Hormones, 2, 119.

Moore, T. \& Tošić, J. (1943). Biochem. J. 37, Proc. xiv.

Olcott, H. S. (1934). J. biol. Chem. 107, 47.

Parker, W. E. \& McFarlane, W. D. (1940). Can. J. Res. 18, 405.

Tošić, J. \& Moore, T. (1944). Biochem. J. 38, Proc. xxvi.

\section{The Free Amino Groups of Insulin}

\author{
By F. SANGER (Beit Memorial Fellow), Biochemical Laboratory, Cambridge
}

\section{(Received 31 August 1945)}

That the free amino groups in proteins may be the $\epsilon$-amino group of lysine was first suggested by Skraup \& Kaas (1906), who failed to isolate lysine from deaminized proteins. Van Slyke \& Birchard (1913) later found an apparent equality between the free amino- $N$ of proteins and one-half of their total lysine-N, which suggested that the free amino groups were due exclusively to such a source. Methods were then developed to confirm the presence of the free $\epsilon$-amino group of lysine in proteins; these consisted in treating a protein with a reagent that would react with free amino groups to give derivatives that were stable to acid hydrolysis, so that on hydrolysis of the substituted protein the derivative of lysine could be isolated. The most satisfactory was that of Gurin \& Clarke (1934), who treated gelatin with benzenesulphonyl chloride, hydrolyzed the resulting benzenesulphonyl gelatin and isolated $\epsilon$-benzenesulphonyllysine from the hydrolysate.

In some proteins, and particularly in insulin, the number of free amino groups (Van Slyke) is far in excess of that which can now be ascribed to lysine, which suggests that the protein must contain residues of certain amino-acids which are condensed in such a way that their $\alpha$-amino groups remain free. Jensen \& Evans (1935) have, in fact, been able to isolate the phenylhydantoin of phenylalanine from a hydrolysate of insulin that had been treated with phenylisocyanate, thus demonstrating that some free amino groups of insulin are present on phenylalanyl residues. Chibnall (1942) has suggested that the free amino groups of proteins over and above the $\epsilon$-amino groups of lysine are due to terminal

Biochem. 1945, 39 residues of polypeptide chains, and that the number of these groups must therefore give a measure of the number of polypeptide chains in the protein.

We found that methanesulphonyl amino-acids were stable to acid hydrolysis and that they could be fractionated by partition chromatography (Gordon, Martin \& Synge, 1943) with an indicator in the aqueous phase of the column. The rates at which the bands moved on the columns were similar to those of the acetamino-acids. The method was satisfactory when applied to synthetic peptides, but with insulin the number of terminal groups estimated by titration of the methainesulphonyl amino-acids was far less than that suggested by the method of Van Slyke. The procedure was accordingly abandoned.

Abderhalden \& Stix (1923) attempted to use 2:4dinitrochlorobenzene (DNCB) for the identification of the terminal groups of a partial hydrolysate of silk fibroin. They did not meet with much success, chiefly owing to the presence of anhydrides in the hydrolysate and the difficulties of separating the products. It seemed, nevertheless, worth while to investigate this reagent, especially as all the 2:4dinitrophenyl-amino-acids (referred to henceforth as DNP-amino-acids) produced are bright yellow, thereby facilitating chromatographic separation. DNCB will not react with amino-acids in $\mathrm{NaHCO}_{3}$ solution unless heat is applied, and this brings about a certain amount of hydrolysis of the protein. Fortunately, however, the corresponding fluorocompound, 2:4-dinitrofluorobenzene (DNFB) was found to react readily at room temperature, and the use of this has met with considerable success, for the DNP-amino-acids produced can be estimated 